\title{
ACQUISITION OF KNOWLEDGE IN VOCATIONAL SUBJECTS USING INTERACTIVE WHITEBOARD
}

\author{
Milan $\check{\boldsymbol{D}} \boldsymbol{U} \boldsymbol{R} \check{S}^{*} *$, Univerzita Mateja Bela v B. Bystrici \\ Miloš BENDÍK, Univerzita Mateja Bela v B. Bystrici
}

Přijato: 2. 11. 2015 / Akceptováno: 29. 3. 2016

Typ článku: Vedecká štúdia

DOI: $10.5507 /$ jtie.2016.007

Abstract: The study paid attention to partial results of the research focusing on implementation of electronic teaching aids and interactive whiteboard in teaching vocational subjects at selected secondary vocational schools in Slovakia. Based on the analysis and interpretation of results of nonstandardized didactic test we compared the achievements of students in the control and experimental group. Using statistical methods we were able to formulate hypotheses.

Key words: empirical research, pedagogical experiment, electronic teaching aids, interactive whiteboard, non-standard didactic test, secondary vocational school.

\section{OSVOJOVANIE VEDOMOSTÍ ŽIAKOV V ODBORNOM PREDMETE S VYUŽITÍM INTERAKTÍVNEJ TABULE}

Resumé: Vštúdii je venovaná pozornost' parciálnym výsledkom výskumu so zameraním na pedagogický experiment implementácie elektronickej učebnej pomôcky s podporou interaktivnej tabule do vyučovania odborného predmetu na vybraných stredných odborných školách v Slovenskej republike. Na základe analýzy a interpretácie výsledkov neštandardizovaného didaktického testu porovnávame dosiahnuté výsledky žiakov $v$ kontrolnej a $v$ experimentálnej skupine. Použitím štatistických metód overujeme formulované pracovné hypotézy.

Kl'účové slova: empirický výskum, pedagogický experiment, elektronická učebná pomôcka, interaktívna tabul'a, neštandardizovaný didaktický test, stredná odborná škola. 


\section{Introduction}

Developed countries of Europe place greater emphasis on the quality of education at all school levels. Such schools promote science and research, implement new and advanced technology and teaching aids. Interactive whiteboard (hereinafter referred to as IW) is one of the new teaching aids and it gradually becomes widely used by pupils, students and teachers. Interactive whiteboard as a modern multimedia means of teaching in schools is from the point of view of its nature, popularity and interest a worldwide phenomenon. Currently, these technical devices are present in almost every school in Europe. The given issue also attracted the attention of the European Schoolnet. European Schoolnet is an organization consisting of 31 European Ministries of Education (including Slovakia), based in Brussels. This non-profit organization focuses on innovations in teaching and learning. Representatives of the Ministries of Education (MoE) has established in 2008 a working group called Interactive Whiteboard Working Group (IW WG) that addresses specific issues with a focus on experience in innovation policy and sharing of best practices regarding IWs. In late 2013, this working group has changed into Interactive Classroom. Nine Ministries of Education (Austria, Estonia, Finland, Ireland, Italy, Lithuania, Norway, Portugal) are currently involved in solving issues regarding interactive classes. Some regional training institutions also actively participate in this working group. The aim of this group is to build on the objectives and activities of the IW WG and disseminate the knowledge on IWs and implement it into individual subjects.

\section{Application of interactive whiteboards in the education in selected countries}

As in many other European countries IWs have become a popular aid also in the Czech Republic. IWs have integrated into teaching process already in 2005 and have since found their place in many schools. From 2005 to 2009 the number of IWs has increased by about five times. At that time schools had one IW an average (Hausner, 2009). At present, the integration of IWs into schools is predominantly dependant on school activities, regional and local grants given by the founder without state support. In 2008 the Czech Republic implemented a project called "Rýchlá šetření roku 2008" under which 4,000 primary, secondary and higher vocational schools were interviewed (www.msmt.cz/vzdelavani/dalsi-vzdelavani/rychla-setreni 2008). The research was eventually attended by 2,827 primary and secondary schools. With the increase in the number of IWs we can observe a greater usability of IWs in individual subjects (Rychlá šetření, 2009). Currently an ongoing modernization of teaching in all schools in the Czech Republic is taking place in order to increase the quality and competitiveness of schools. Increase in the number of installed and used interactive whiteboards, as a new phenomenon of illustrative interactive learning, is clearly visible both in terms of its wide application, as well as in terms of its popularity.

One of the pioneers in the implementation of IWs in the education process in Europe was the United Kingdom. The government and the Department for Education invested great resources not only in the integration of IWs into the educational process, but they also encouraged and supported the use of all modern information and communication technologies throughout the whole education system (Levy, 2002). The fact that nowadays UK has IWs in almost every class of primary and secondary schools is 
the result of long-term and systematic support in ICT field. Already in 2000, the schools had been involved in very ambitious plans for continuing professional development of teachers funded through the so-called. "New Opportunities Fund" amounting to 230 million lbs. The aim of the project was to provide about 30 hours of ICT training for virtually all primary and secondary school teachers.

In the same period (2000 - 2001) yet another study took place (Levy, 2002). The study focused on the introduction of IWs in the teaching process in two secondary schools (City School and Yewlands) in Sheffield. This study was initiated and implemented in Sheffield City Learning Centres by Professor P. Levy. The study observed 17 classes ( 8 classes at the City School and 9 classes on Yewlands) in various educational fields. A total of 11 interviews with teachers (6 interviews at the City School, 5 at Yewlands) were conducted. The aim of these interviews was to examine how teachers and pupils perceive IW in teaching process and highlight/ draw attention to problems that arise in the early stage of IW introduction to the learning process. Levy argues that teachers have reported a number of benefits associated with the use of IW, such as a simple and effective method for demonstrating educational software. Using information prepared in advance greatly reduces time spent on traditional blackboard writing.

Interactive whiteboard offers a wealth of information and educational materials; materials drawn up on IWs can be saved and reused. Ways in which the board can be used to facilitate interaction in the classroom involves the use of IWs as an effective incentive for teacher - student and student - student interaction. It is an effective means to enable pupils to present and discuss their work. Levy summed up the positive evaluation regarding IW in the following points:

- IW can offer fun and interesting learning,

- IW can help teachers with more efficient and interactive explanation of subject matter,

- IW can improve educational outcomes and increase motivation of pupils.

Levy, however, emphasizes that the important word here is "can." Modern technology is just another mean of classroom help. The course of actual teaching fully depends on the personality of each teacher.

In the following years many other research studies regarding the integration of IWs in schools took place as the use of IWs was gradually increasing.

The UK government believes in IWs so much it has invested 50 million lbs into IWs in 2010, which represents a fifth of the budget for the integration of ICT in the education processes and this trend still continues. A research report on the Multiannual Use of IWs in Teaching was later published in England. The report stated several IW benefits for teachers and pupils and also some factors affecting the effective use of IW.

\section{General advantages of IW:}

- versatility - suitable for all age groups across the curriculum (Smith, 1999),

- more opportunities for interaction and discussion in the class, especially when compared to other DT (Gerard, et al., 1999),

- increases the pleasure of learning for pupils and teachers thanks to more colorful and dynamic resources (Levy, 2002). 


\section{Advantages for teachers:}

- allows the teacher to integrate DT into teaching (Smith, 2001),

- encourages spontaneity and flexibility that thus enable teachers to interactively use and control a wide range of online information sources (Kennewell, 2001),

- allows the teacher to save and print everything he/she does, including notes, teachers have a permanent record of their work which may vary according to their needs,

- inspires teachers to change their methodology of work in favor of DT and supports their career development (Smith, 1999).

\section{Advantages for pupils:}

- greater motivation and fun,

- greater involvement, development of personal and social skills (Levy, 2002),

- less writing on paper,

- mastering more complex tasks thanks to clearer, more effective and dynamic presentation on IWs (Smith, 2001),

- use of different learning styles and resources so as to meet the needs of all pupils and students (Bell, 2002),

- greater creativity and personalization, boost of confidence (Levy, 2002).

\section{Factors affecting the effective use of IW:}

- free availability of IWs (Levy, 2002),

- the use of IWs by pupils (Kennewell, 2001),

- training for teachers (Levy, 2002),

- the possibility of exchanging ideas and resources among teachers (Levy, 2002),

- the correct positioning of IWs in class (Smith, 2001),

- high level of reliability and technical assistance to minimize problems with IW without burdening users (Levy, 2002), (Adamek a kol. 2010).

In January 2004 representatives of the Danish Ministry of Education visited the exhibition of modern technology BETT in London. (http://www.bettshow.com/bett/ website/ Default.aspx?refer=1>). They got familiar with the concept of introducing IWs in education, which inspired them to start the same project within the same year and finance its implementation in primary and lower secondary schools for two more years. The project attracted three schools (Risgaard, 2010) Grantofteskolen in Ballerup, Overlund Skole in Viborg and Rugkobbelskolen in Aabenraa. The project was a part of a wider project ITIF focusing on the introduction of ICT in schools. Based on past experience of the United Kingdom, the main objective of the project was to determine the potential of IWs with regard to:

- professional development of teachers and their competence,

- development of pupils' competence in all subjects,

- new aspects of learning and teaching techniques (i.e. learning proves, the use of digital learning resources etc.),

- effect on daily teaching and learning in the classroom.

Following the project a website http://IT.emu.dk was created where students and teachers can draw inspiration for their own learning (or teaching) in Danish or English. Teachers met the expectations of the Ministry of Education and used IWs widely. According to the results of the questionnaire, interviews with teachers and analysis 
of observed lessons it was clear that not all teachers used IWs in the same way. Some teachers used it on almost all lessons, others combined a conventional blackboard teaching and IWs, and some used it only rarely. IWs were used for several different purposes, such as:

- finding information on the Internet (maps, images, Google etc..),

- presentation of pupils' works,

- introducing new educational topics,

- films, TV, videos from the Internet,

- summary of previous lectures,

- evaluation of teaching processes and pupils' projects.

In 2008-2009 the Danish Evaluation Institute (EVA) conducted a study $(<\mathrm{Https}: / /$ www.eva.dk/>) that involved 11 schools in 11 different cities in Denmark. Systematic observation of teaching, questionnaires and discussions with teachers the study brought a number of interesting findings on the use of IWs:

- Use of IWs in the classroom supports different elements of ICT integration in general. It seems that ICT is used more often and more spontaneously in classrooms that are not specialized in ICT.

- Teachers and students increasingly use digital presentations and multimedia resources from Internet websites (text, audio, video, etc.).

- Teachers prefer to use IWs in the classrooms they visit every day instead of having to go to specialized classrooms where pupils come only once or twice a week.

- Teachers emphasize that students spend less time writing on the blackboard when presenting their works. Everything can now be prepared at home and then present it on IW to the whole class.

- A group of experts evaluated the results of the study and recommended that the board was turned on all day. They claim that teachers do not lose time turning it on and pupils can work with it during breaks. This option will contribute to their education and acquisition of information and communication skills while working with IWs (Risgaard, 2010).

An interesting example with regard to IWs is Finland. Students of this country score the highest in the international comparative tests PISA. (http://www.pisa.oecd.org).

Neumajer (2008) states that Finland did not immersed itself in the interactive technologies as much as the United Kingdom. Modern Finnish classrooms are not overwhelmingly equipped with IWs. Finns say that such an investment is too expensive to be worth it, and they rather use multimedia computers connected to the Internet and project images directly on the screen. This technology is present in two-thirds of all the classes. We have to point out, however, that classrooms featuring IWs use them often and efficiently. Neumajer also states that he personally witnessed situations where representatives of the British Department for Education stated Finns use IWs more effectively than they do back in the UK. It shall be noted that Finland, unlike the UK, does not have a special government program for ICT in education and no one there massively pushes for this expensive equipment to be used in schools. Finland's education expenditures rank among world's average.

In 2007, the Austrian Ministry of Education (BMUKK) launched an initiative called Futur (e) learning which supports new forms of teaching and learning using ICT in 
education. The authors of the initiative came to the conclusion that IWs are a modern approach to teaching and that IWs have the potential to become teaching boards of the third millennium. According to the survey (Lehner, 2010) conducted in 2008, 21\% of state schools featured IWs. Following the results of the initiative Future (e) learning the Austrian Ministry of Education has launched several projects to assess the use of IWs in the education process. These projects included various types of schools, boards and software. One of the projects (Lehner, 2010) aimed at introducing IWs into three Upper Austrian schools (secondary school and two grammar schools). Students and teachers were enthusiastic about using IWs and appreciated their role in education. Participants gave IWs an average rating of 1.3 (1 - best grade, 4 - the worst grade (http://www.elc20. com/index.php>).

In Switzerland there are no programs or statistics dealing with the integration of IWs into schools. School boards are mostly purchased by municipalities from the school equipment budget, not from the budget for ICT (Burton, 2010).

Much like in the Czech Republic and other developed countries in Europe (excluding the UK), IWs have began to emerge in Slovakia around the year 2005 and gradually become a part of education in most schools of various types.

According to the Informatisation Concept of the Ministry of Education in the Slovak Republic with a view to 2020 - DIGIPEDIA 2020 - the gradual introduction of digital curriculum through interactive whiteboard in regional education should take place in two phases. First of all it is necessary to finish digital curriculum for all levels of education in kindergartens, primary, special and secondary schools. The ultimate goal of the concept is to reach the second phase at which the digital education will be accessible to all students and will thus also benefit their parents, teachers, schools and society. (http://www.minedu.sk)

Primary and secondary schools in Slovakia are being gradually equipped with IWs. One of the priorities of educational policy in Slovakia is to equip primary and secondary schools with computer technology, modern teaching aids, interactive whiteboard and the like. This initiative is to be implemented not only at the national level but also through using European funds. One of such projects is the national project SR - ITMS project code: 26110130549 Supporting Guidance of Primary School Pupils for Vocational Education and Training through the Development of Polytechnic Education Aimed at Developing Job Skills and Working with Talent. The project was successfully implemented in the years 2013-2015. In 2016 the national project aimed at continuing education of teachers of primary and secondary schools will take place, utilizing the latest teaching aids and information and communication technologies in order to support modern teaching and transform traditional schools into modern ones.

A number of research groups and teams address the issue of using interactive whiteboards in Slovak primary and secondary schools. One of the first to deal with the issue in question was EDEA PARTNERS, a.s. (a company providing expert and project services in the fields of education, employment and social inclusion) (http://www.rirs.iedu.sk/Dokumenty). The company has undertaken to carry out a scientific research in this field. The aim of the research study was to analyze the use of interactive whiteboards in education at primary and secondary schools and evaluate their impact on the quality of the teaching process and the development of pupils' 
competence. The entire research sample consisted of 2,245 respondents (directors of primary and secondary schools, teachers, pupils, parents). This research study was conducted under the initiative of the Institute of Information and Prognosis of Education.

According to this study $27 \%$ of teachers have been using IWs for more than two years. Almost $22 \%$ of teachers have been using IWs for less than half a year. More than $44 \%$ of teachers use IWs daily/ almost daily, more than two-thirds of teachers use IWs at least once a week and more than $18 \%$ of teachers use IWs less frequently (EDEA PARTNERS, a.s. 2011). The study further states inter alia that the IWs are mostly used during Mathematics (almost 20\%), followed by foreign languages (16\%) and Slovak language $(13.5 \%)$. IWs are least used in teaching vocational subjects $(8 \%)$. The conclusions of this study do not clearly define which skills IWs develop in pupils.

The issue focuses on the acquisition and development of key competencies of pupils, and it is the main goal of education as set out in the Education Act of 2008 (Act no. 245/2008 Z.z. of $22^{\text {nd }}$ May 2008). Research on the impact of interactive whiteboard on pupils' competences had not been conducted in Slovakia until 2013.

This problem has been tackled by a team from two departments (FHPV Prešov, FPV UMB in Banská Bystrica and PF UKF in Nitra) in the years 2013 to 2015 under the guidance of the principal investigator (prof. PaedDr. J.Pavelka, PhD.) under the project KEGA no.: 015P-4/2013 entitled Implementation Methods for IWs in Teacher Training of Technology, Physics and Mathematics for Lower Secondary Education. The aim of the project was to propose and verify appropriate methodologies and teaching strategies with the use of IWs in physics and mathematics lessons. The results are published in university textbooks (Duris, Pavelka, Bendik et al., 2015) and monographs (Pavelka, Kozík, Bendik et al. 2015), which are also the outcome of the project.

\section{Objectives and methods of the research}

The Slovak Republic is no exception in upgrading traditional classroom and specialized classrooms in primary and also in secondary vocational schools (SVS) with IWs.

The issue of implementation of interactive whiteboards in teaching process in secondary vocational schools, especially in three-years apprenticeship study programmes, in Slovakia is still relatively little studied field. This is connected with the fact that the use of IWs in the educational process is closely linked with the creation and application of electronic teaching aids for teaching interactive experience.

One of the objectives of our research was to determine, on the basis of pedagogical experiment, whether the proposed and used electronic teaching aid (ETA) with the support of IWs will statistically affect students' knowledge in the educational process of the vocational subject Materials. The attention was given to the thematic units Coniferous and Deciduous Trees in the three-year apprenticeship programme Carpenter. Students' knowledge in the given subject was tested using non-standardized achievement test (AT) of our own design. The pedagogical experiment featured control and experimental group of students. In the experimental group teaching process used ETA with IWs, the control group was taught without ETA and IWs.

To meet the stated objectives we used various methods featuring the following research methods and techniques of empirical research: 
1. The literary method and content analysis of educational documents were used as a part of the comprehensive knowledge of the issue. When studying academic literature, attention was focused mainly on scientific and professional publications, yearbooks, magazines, and peer-reviewed Internet resources.

2. The method of excerpts evaluation, processing and sorting. This method was used in the integration processing of the relevant information necessary for a specific issue.

3. Natural pedagogical experiment - as the main method of research.

4. Non-standardized entry achievement test to divide students into control and experimental groups.

5. Non-standardized final achievement test as a tool to verify the knowledge of students who have been observed in the control and experimental group. (Verifying the hypotheses $\mathrm{H}_{1}, \mathrm{H}_{2}$ ).

6. Analyzes of the test answers using difficulty index.

7. When processing the results of both achievement tests we used quantitative and qualitative methods.

Statistical evaluation of the data obtained from educational research uses testing methods that can be divided into parametric and nonparametric. Parametric tests have greater potential, so if possible, we use them. The use of parametric tests, however, is linked to certain distribution assumptions (for example, the assumption of a normal distribution, the assumption of equal variability). If the conditions pre-determining the use of parametric tests are not met, non-parametric tests can be used. The use of nonparametric test does not require the calculation of statistical parameters or the knowledge of the basic sample division. Therefore prior to hypotheses testing it was necessary to examine the assumption of normal distribution of files (sets). For this purpose we used two types of test - Kolmogorov-Smirnov test and Shapiro-Wilk test.

\section{Kolmogorovov-Smirnov test}

Kolmogorov-Smirnov one-sample test tests the hypothesis of correspondence between empirical and theoretical distribution, which can also be used in those cases where the $\chi^{2}$ - test is not recommended. This test allows for testing the conformity of empirical and theoretical distribution function in the case of continuous theoretical distribution function with known parameters. We test the null hypothesis $\mathrm{H} 0$ that probable empirical and theoretical distributions are not statistically significant when compared to the alternative hypothesis that states that they do differ (http://www.km.fpv.ukf.sk/).

\section{Shapiro-Wilk test}

This test is one of the most widely used tests for testing normality of distribution of small files, although it was later extended to the large samples. The hypothesis testing should also consider whether the random sample comes from a normal distribution. In this case, if the range $\mathrm{n}$ of random selection applies to $\mathrm{n} H 0 \in\{7,30\}$, the ShapiroWilk test should be used.

\section{Wilcoxon signed-rank test}

Wilcoson signed-rank test is a non-parametric analogy of t-test. $\left(X_{1}, X_{2}, \ldots, X_{m}\right)$ a $\left(Y_{1}, Y_{2}, \ldots, Y_{m}\right)$ are two independent random samples of two continuous divisions. We have verified the null hypothesis $\mathrm{H} 0$ - both selections are from the same basic type the distribution functions of the two divisions are the same. The alternative hypothesis 
states that the distribution functions of both divisions are different. The calculations use the following statistics:

$$
U_{1}=m \cdot n+\frac{m(m+1)}{2}-T_{1}, \quad U_{2}=m \cdot n+\frac{n(n+1)}{2}-T_{2}
$$

If the ranges $m, n$ are large numbers $(m>30, n>20)$, the test criterion will be the statistics:

$$
U=\frac{U_{1}-\frac{1}{2} m \cdot n}{\sqrt{\frac{m \cdot n}{12}(m+n+1)}},
$$

In some literature and statistical programs Wilcoxon test can also be found under the name of Mann - Whitney test. (http://www.km.fpv.ukf.sk)

\section{Pre-research stage - analysis and interpretation of results of the final achievement test}

Based on the analysis of the performance and content standards and the thematic educational plan for the vocational subject Materials we have created a matrix consisting of the final non-standardized achievement test questions. From the matrix we chose those questions that focus on essential matters each student is required to know and master. The final achievement test contained 16 questions and students were given 20 minutes to complete it. Questions focused at two levels Niemierko's taxonomy of educational objectives, understanding and the specific transfer.

Questions no. $1-5$ are multiple choice questions, ie, one of the available options is correct (1 point). Student gets 0 points for wrong answer.

Questions no. 6 - 11 are open tasks with brief answers. Completely correct answer 2 points, partially correct answer -1 point, incorrect answer 0 points.

Questions no. 12 - 16 are multiple choice questions, ie, one of the available options is correct (1 point). Student gets 0 pints for wrong answer.

The maximum number of points a student could get was 22 points. Final test questions were drawn up in cooperation with qualified teachers teaching the subject Materials.

Pre-research was conducted in order to verify the proposed questions in the final AT and also to verify whether the time for completing the test is sufficient. Pre-research was conducted on a sample of 10 students, and the results are presented in Table. 1. Specific percentages are presented in Figure 1.

Table 1 Results of pre-research final AT

\begin{tabular}{|l|c|c|c|c|c|c|c|c|c|c|c|c|}
\hline Student: & $\mathbf{1}$ & $\mathbf{2}$ & $\mathbf{3}$ & $\mathbf{4}$ & $\mathbf{5}$ & $\mathbf{6}$ & $\mathbf{7}$ & $\mathbf{8}$ & $\mathbf{9}$ & $\mathbf{1 0}$ & $\begin{array}{l}\text { In } \\
\text { total }\end{array}$ & $\begin{array}{c}\text { Difficulty } \\
\text { index P }\end{array}$ \\
\hline $\begin{array}{l}\text { Question } \\
\text { no.1 }\end{array}$ & 1 & 1 & 1 & 1 & 1 & 0 & 1 & 1 & 1 & 1 & 9 & 90 \\
\hline $\begin{array}{l}\text { Question } \\
\text { no.2 }\end{array}$ & 1 & 0 & 0 & 1 & 1 & 1 & 1 & 1 & 1 & 1 & 8 & 80 \\
\hline
\end{tabular}




\begin{tabular}{|l|c|c|c|c|c|c|c|c|c|c|c|c|}
\hline $\begin{array}{l}\text { Question } \\
\text { no.3 }\end{array}$ & 0 & 0 & 1 & 1 & 1 & 1 & 1 & 1 & 0 & 1 & 7 & 70 \\
\hline $\begin{array}{l}\text { Question } \\
\text { no.4 }\end{array}$ & 1 & 1 & 0 & 1 & 0 & 1 & 1 & 1 & 1 & 1 & 8 & 80 \\
\hline $\begin{array}{l}\text { Question } \\
\text { no.5 }\end{array}$ & 0 & 1 & 1 & 1 & 1 & 0 & 1 & 1 & 1 & 1 & 8 & 80 \\
\hline $\begin{array}{l}\text { Question } \\
\text { no.6 }\end{array}$ & 1 & 1 & 2 & 2 & 2 & 1 & 2 & 2 & 1 & 2 & 16 & 80 \\
\hline $\begin{array}{l}\text { Question } \\
\text { no.7 }\end{array}$ & 2 & 1 & 1 & 2 & 2 & 1 & 2 & 2 & 0 & 2 & 15 & 75 \\
\hline $\begin{array}{l}\text { Question } \\
\text { no.8 }\end{array}$ & 2 & 1 & 1 & 2 & 1 & 1 & 1 & 1 & 1 & 1 & 12 & 60 \\
\hline $\begin{array}{l}\text { Question } \\
\text { no.9 }\end{array}$ & 1 & 1 & 1 & 2 & 1 & 1 & 0 & 1 & 1 & 2 & 11 & 55 \\
\hline $\begin{array}{l}\text { Question } \\
\text { no.10 }\end{array}$ & 1 & 1 & 1 & 2 & 2 & 3 & 2 & 2 & 1 & 2 & 17 & 85 \\
\hline $\begin{array}{l}\text { Question } \\
\text { no.11 }\end{array}$ & 2 & 2 & 2 & 2 & 1 & 2 & 2 & 2 & 2 & 2 & 19 & 95 \\
\hline $\begin{array}{l}\text { Question } \\
\text { no.12 }\end{array}$ & 1 & 1 & 1 & 1 & 1 & 0 & 1 & 1 & 1 & 1 & 9 & 90 \\
\hline $\begin{array}{l}\text { Question } \\
\text { no.13 }\end{array}$ & 1 & 1 & 1 & 1 & 1 & 0 & 1 & 1 & 1 & 1 & 9 & 90 \\
\hline $\begin{array}{l}\text { Question } \\
\text { no.14 }\end{array}$ & 0 & 0 & 1 & 1 & 1 & 1 & 1 & 1 & 0 & 1 & 7 & 70 \\
\hline $\begin{array}{l}\text { Question } \\
\text { no.15 }\end{array}$ & 0 & 0 & 1 & 1 & 1 & 1 & 1 & 1 & 1 & 1 & 8 & 80 \\
\hline $\begin{array}{l}\text { Question } \\
\text { no.16 }\end{array}$ & 1 & 1 & 0 & 1 & 1 & 0 & 1 & 1 & 0 & 1 & 7 & 70 \\
\hline $\begin{array}{l}\text { Total } \\
\text { points : }\end{array}$ & 15 & 13 & 15 & 22 & 18 & 14 & 19 & 20 & 13 & 21 & Average: \\
\hline \multicolumn{1}{c}{$\%$} & 68 & 59 & 68 & 100 & 82 & 64 & 86 & 91 & 59 & 95 & $77 \%$ \\
\hline
\end{tabular}

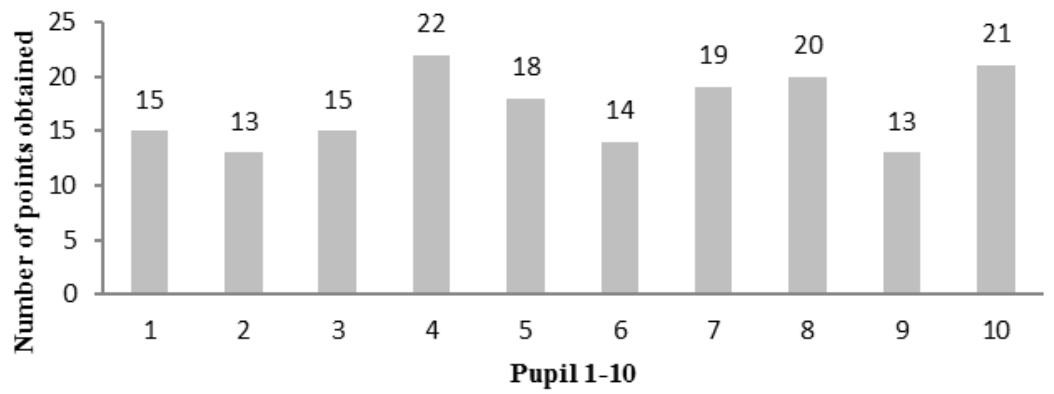

Figure 1 Overview of students and their results in the final AT 
The results of the pre-research are as follows:

- students understood the questions of the final AT,

- the average rate of the final AT was $77 \%$,

- wording of some questions was stylistically modified for better understanding of students,

- the proposed time (20 minutes) is sufficient.

\section{Difficulty index of the final AT}

Sensitivity is one of the basic characteristics of the AT and its questions. When analyzing the answers for each question of the AT it is necessary to calculate the difficulty index of each task. The more students successfully solve the question, the easier the question is and vice versa.

When calculating the index of difficulty we considered the following relationship:

$$
\mathbf{P}=100 \times \frac{n_{z}}{n}[\%]
$$

P- difficulty index,

$\mathbf{n}_{\mathbf{s}^{-}}$the number of students in the group who solved the question correctly,

n- the number of all students in the group.

Individual tasks with the calculated P - Index of difficulty are present in the Figure 2.

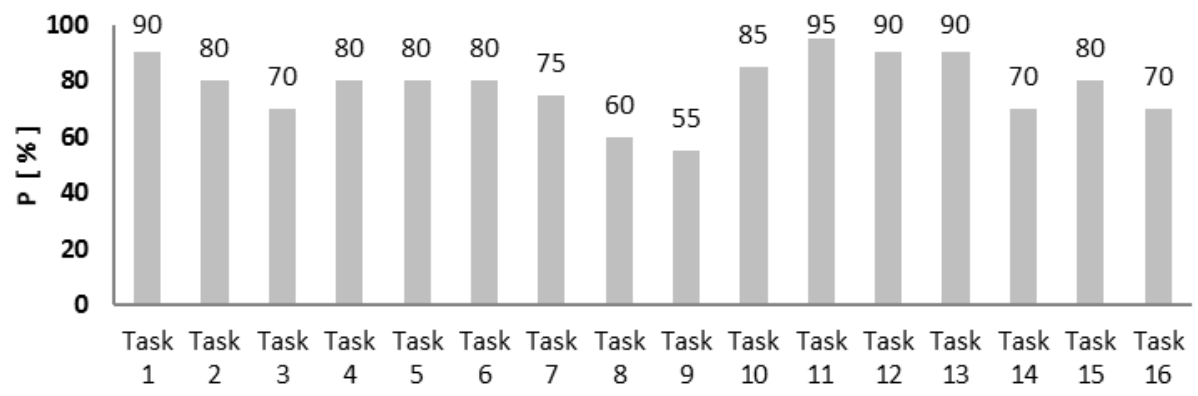

Figure 2 Difficulty index of the final AT

When drawing up a test, we can manipulate with its difficulty. If the aim of the test is to test the rate of learned curriculum, test questions should be easier but reasonably difficult at the same time. The aim of the AT is to find out what students do know and not what they do not know. This means that we should leave out the difficult questions when drawing up this type of test. The difficulty of a tests is determined in advance on a similar sample of students (Gavora a kol. 2010).

As shown in Figure 2 questions no. 1,11,12,13 in the proposed final AT have a fairly high difficulty index ( $80 \%$ to $95 \%$ ). These are very easy questions since students of three-year apprenticeship programme Carpenter are students from lower performance spectrum (average to below-average performance). These questions also have 
the incentive character. Very difficult tasks are those having a low index of difficulty (10\% to $20 \%$ ). In our case such questions are not present in the final AT.

Students in the pre-research final AT passed the test at the satisfying level. Therefore from the technical and didactic point of view the final non-standard AT test can be considered suitable for students in the control and experimental groups and can be used in the research.

\section{Results of the final AT}

After finishing the topic of Coniferous and Deciduous Trees in the subject Materials, where the experimental group was taught with ETA and IWs and the control group was taught without ETA and IW, students of both groups took the final AT.

Performance of both groups was evaluated on the basis of the statistical indicators presented in Table. 2 and in Figure 3-6.

Table 2 Comparison of the test results

\begin{tabular}{|c|c|r|c|c|c|c|}
\hline $\begin{array}{c}\text { Achieved } \\
\text { points }\end{array}$ & $\begin{array}{c}\text { Control } \\
\text { group }\end{array}$ & $\begin{array}{c}\text { Points } \\
\text { in total }\end{array}$ & Percentage & $\begin{array}{c}\text { Experimental } \\
\text { group }\end{array}$ & Percentage & $\begin{array}{c}\text { Points in } \\
\text { total }\end{array}$ \\
\hline 13 points & 1 & 13 & 0,79 & 0 & 0,00 & 0 \\
\hline 14 points & 4 & 52 & 3,17 & 0 & 0,00 & 45 \\
\hline 15 points & 17 & 255 & 13,49 & 3 & 2,38 & 160 \\
\hline 16 points & 31 & 496 & 24,60 & 10 & 7,94 & 476 \\
\hline 17 points & 43 & 731 & 34,13 & 28 & 22,22 & 558 \\
\hline 18 points & 20 & 360 & 15,87 & 31 & 24,60 & 684 \\
\hline 19 points & 4 & 76 & 3,17 & 36 & 28,57 & 220 \\
\hline 20 points & 2 & 40 & 1,59 & 11 & 8,73 & 84 \\
\hline 21 points & 1 & 21 & 0,79 & 4 & 3,17 & \\
\hline 22 points & 3 & $\mathbf{6 6}$ & 2,38 & 3 & 2,38 & \\
\hline In total : & $\mathbf{1 2 6}$ & $\mathbf{2 1 1 0}$ & $\mathbf{7 6 , 1 1}$ & $\mathbf{1 2 6}$ & $\mathbf{8 2 , 7 2}$ & $\mathbf{2 2 9 3}$ \\
\hline
\end{tabular}

The given indicators suggest the experimental group students were more successful and got 2,293 points $(82.72 \%)$ of the total possible number of points $(22 \times 126=2772$ pts.). Students in the control group got a total of 2,110 points $(76,11 \%)$. The total difference between the control and experimental group is 183 points $(6,6 \%)$. 


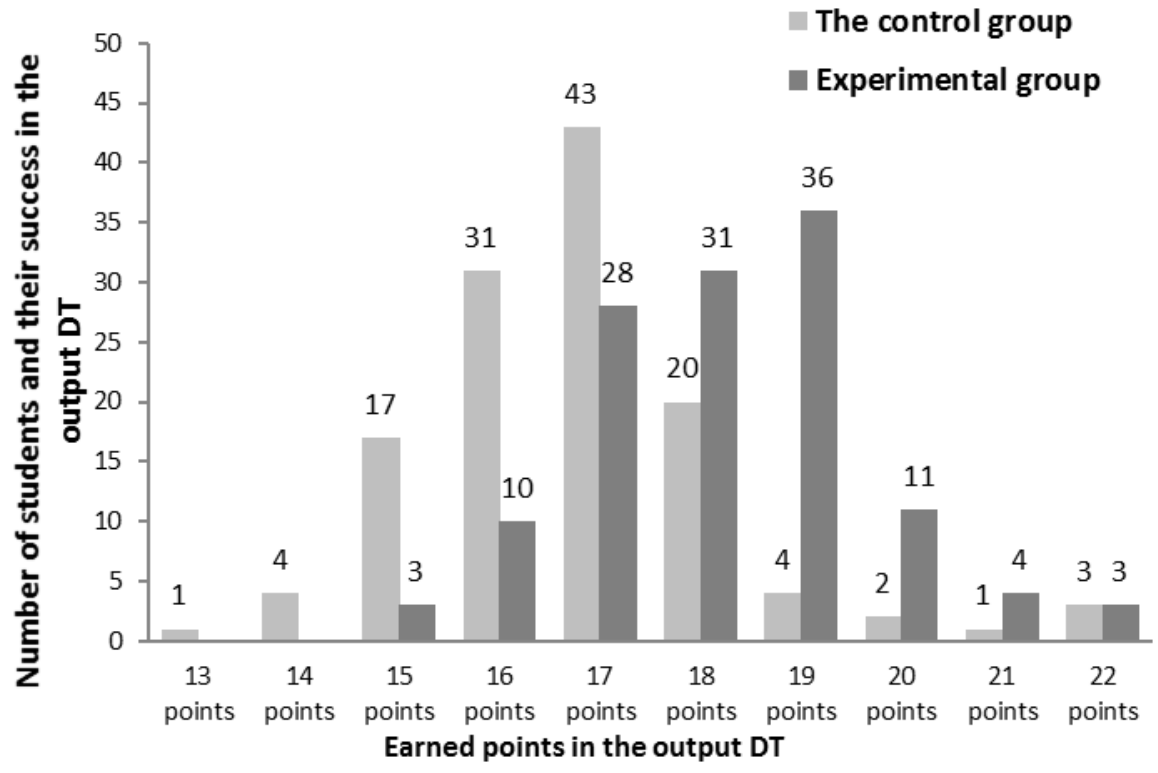

Figure 3 Comparison of the test results of the control and experimental group

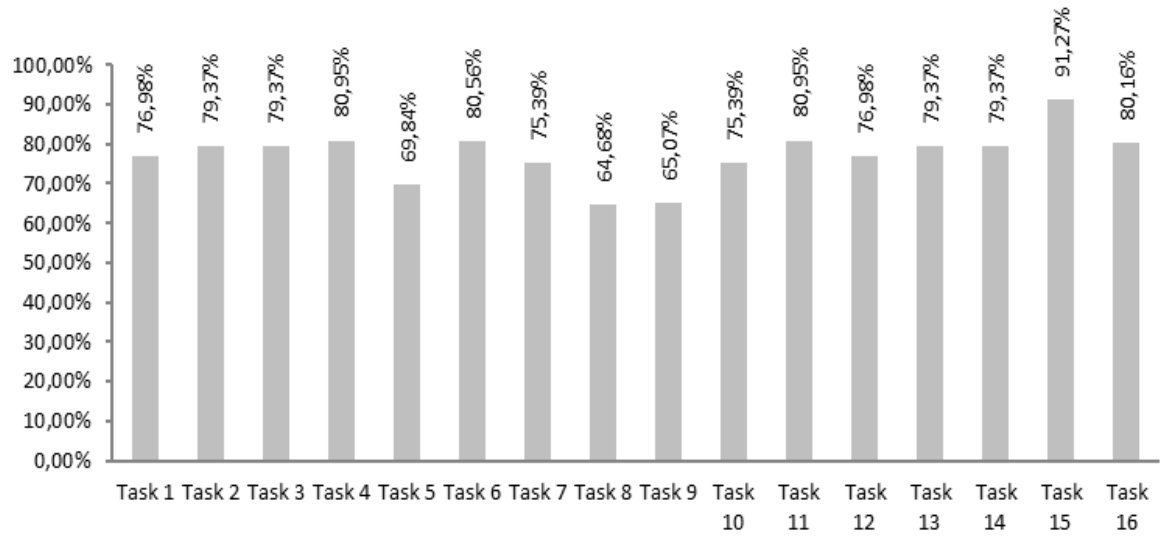

Figure 4 Overall results of the control group 


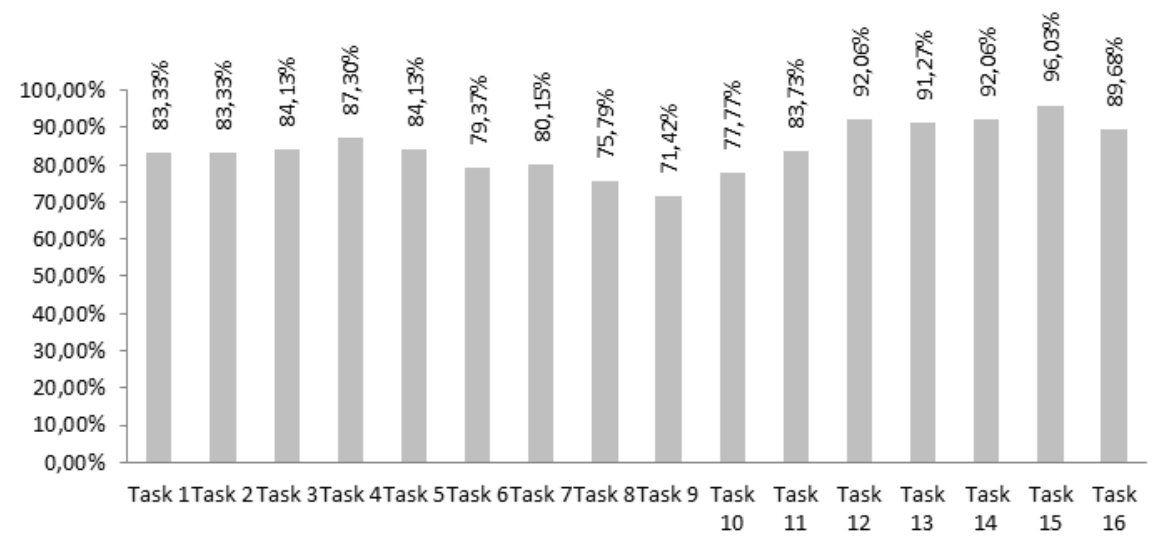

Figure 5 Overall results of the experimental group

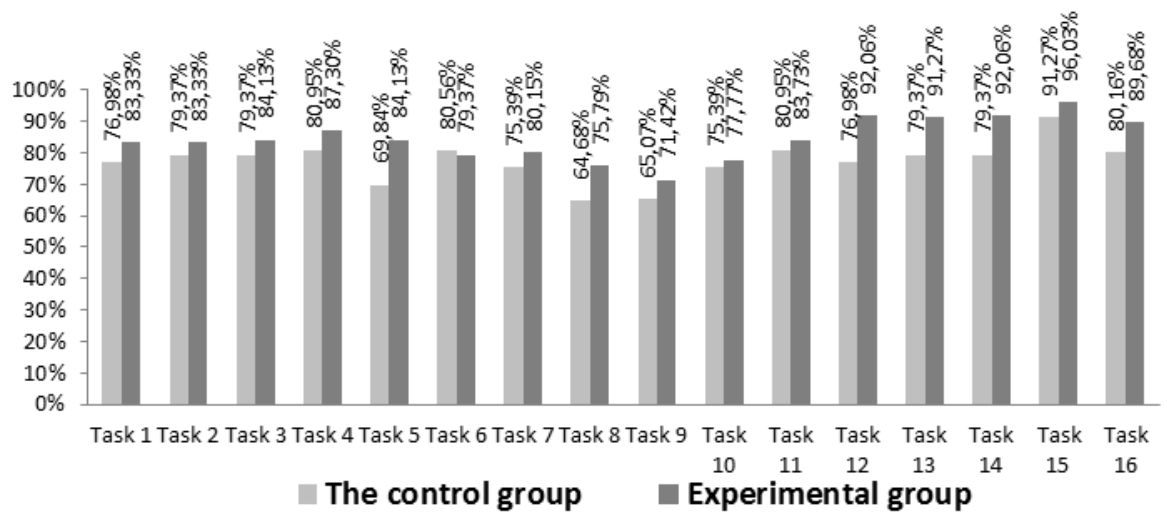

Figure 6 The overall question results - control group

\section{Validity and reliability of the final achievement test}

Validity of the test - means appropriateness of the test. As the test mostly observed content validity, teachers did not have objections to the proposed final AT and recommended it for testing the students after completing the whole course (for both the control and experimental group).

Reliability of the test - indicates to what extent is the proposed final AT accurate and reliable. To determine the reliability we used Kundert-Richardson formula. Reliability coefficient: 


$$
\begin{gathered}
r_{k r}=\frac{k}{k-1} \cdot\left(1-\frac{\sum p q}{s^{2}}\right) \\
r_{k r}=\frac{16}{16-1} \cdot\left(1-\frac{2.42}{6,21}\right) \Rightarrow r_{k r}=0,651
\end{gathered}
$$

where:

$\mathbf{k}$ - number of questions in the test,

$\mathbf{p}$ - the proportion of students who answered the question correctly,

$\mathbf{q}=1-\mathrm{p}$,

$\mathbf{s}^{2}-$ it is a standard deviation for the overall performance of students in the test

Method for calculating test reliability :

- in the first step we express the standard deviation - s2, which is needed for KunderaRichardson's formula,

- in the second step we calculated $\mathbf{p}$ - proportion of students who answered correctly the and $\mathbf{q}$ - the proportion of students who answered incorrectly.

- reliability coefficient of the AT - rkr.

The higher the reliability coefficient, the more accurate and reliable instruments for which the rate is calculated is. The higher the reliability of the tool (eg. AT), the lower the influence of luck on the outcome of the AT. Although the scale for rating the reliability coefficient ranges between 0 and 1 , in non-standardized tests the reliability coefficient usually ranges between 0,55 and 0,80 .

\begin{tabular}{|c|c|c|c|c|c|}
\hline Question no. & No. of correct answeres & $\mathrm{p}$ & $\mathrm{q}$ & p.q & $\mathbf{r k r}$ \\
\hline 1 & 202 & 0,80 & 0,20 & 0,16 & \multirow{17}{*}{0,651} \\
\hline 2 & 205 & 0,81 & 0,19 & 0,15 & \\
\hline 3 & 206 & 0,82 & 0,18 & 0,15 & \\
\hline 4 & 212 & 0,84 & 0,16 & 0,13 & \\
\hline 5 & 194 & 0,77 & 0,23 & 0,18 & \\
\hline 6 & 201,5 & 0,80 & 0,20 & 0,16 & \\
\hline 7 & 196 & 0,78 & 0,22 & 0,17 & \\
\hline 8 & 177 & 0,70 & 0,30 & 0,21 & \\
\hline 9 & 172 & 0,68 & 0,32 & 0,22 & \\
\hline 10 & 193 & 0,77 & 0,23 & 0,18 & \\
\hline 11 & 207,5 & 0,82 & 0,18 & 0,15 & \\
\hline 12 & 213 & 0,85 & 0,15 & 0,13 & \\
\hline 13 & 215 & 0,85 & 0,15 & 0,13 & \\
\hline 14 & 216 & 0,86 & 0,14 & 0,12 & \\
\hline 15 & 236 & 0,94 & 0,06 & 0,06 & \\
\hline 16 & 214 & 0,85 & 0,15 & 0,13 & \\
\hline \multicolumn{4}{|c|}{ Spolu S } & 2,42 & \\
\hline
\end{tabular}

Table 3 Values of DT reliability 
The results show us that the designed final non-standard achievement test exhibits the desired degree of reliability - reliability coefficient is 0,651 . (Table 3 ). With regard to generally recognized reliability borders indicated by Rosa (2007, p. 34), our AT is reliable and accurate. Based on the results the AT can be deemed relevant and we can use it for other verification procedures.

\section{Verification of hypotheses $\mathrm{H}_{1}$ a $\mathrm{H}_{2}$}

We stated already in the beginning that one of the aims of the research was to determine whether the proposed ETA and IWs and their use in the educational process would affect students' knowledge.

To verify the above objective we have formulated the following hypotheses $\mathbf{H}_{1}$ and $\mathbf{H}_{2}$ :

\section{Hypothesis $\mathrm{H}_{1}$ :}

Students using electronic teaching aids with IWs during the thematic units Coniferous and Deciduous Trees reach better results in the final AT than students without ETA and IWs. This difference is statistically significant in favor of the experimental group.

\section{Hypothesis $\mathrm{H}_{2}$ :}

Students using electronic teaching aids with IWs during the thematic units Coniferous and Deciduous Trees reach better results in the field of specific transfer than students without ETA and IWs. This difference is statistically significant in favor of the experimental group.

To confirm or refute the working hypothesis we used basic descriptive statistics clearly presented in the Table. 4.

The summary table (Table no. 4) include all the basic descriptive statistics horizontally divided into Comprehension and Specific transfer and vertically into CG and EG. The results are as follows:

The first line in both levels specifies the number of students who were tested - 126 in total. The second line is the average of points obtained for each level. The standard deviation shown in the line 3 is characterized by the variability - how widely are values distributed in a set of values. The sixth line indicates a median value for each selection, ie the median. With regard to the median difference between CG and EG in case of the specific transfer there is no variation and in case of comprehension, the median is only one point higher in the experimental group. The table also listed minimum and maximum values of files. The value of 25 . percentile is also called 1st quartile and shows what values are being reached by $25 \%$ of the group. 75 . percentile value also called $3^{\text {rd }}$ quartile shows what values are being reached by 75\% of the group (Hill, Smith, 2010 p..2). http://www.psychiatriepropraxi.cz/pdfs/psy/2010/02/11.pdf. 
Table 4 Basic descriptive statistics for $\mathrm{H}_{1}$ and $\mathrm{H}_{2}$

\begin{tabular}{|ll|r|r|r|}
\hline & & \multicolumn{3}{|c|}{ Group } \\
\cline { 3 - 5 } & Control & Experimental & \\
CG & EG & In total \\
\hline Comprehension & Number of & 126 & 126 & 252 \\
& Arithmetic average & 11,99 & 13,14 & 12,57 \\
& Standard deviation & 1,45 & 1,34 & 1,51 \\
& Minimum & 8 & 10 & 8 \\
& 25. percentile & 11 & 12 & 11,3 \\
& Median & 12 & 13 & 13 \\
& 75. percentile & 13 & 14 & 14 \\
& Maximum & 16 & 16 & 16 \\
\hline Specific transfer & Number of & 126 & 126 & 252 \\
& Arithmetic average & 4,79 & 5,06 & 4,92 \\
& Standard deviation & 0,90 & 0,80 & 0,86 \\
& Minimum & 2 & 2 & 2 \\
& 25. percentile & 4 & 5 & 4 \\
& Median & 5 & 5 & 5 \\
& 75. percentile & 5 & 6 & 6 \\
& Maximum & 6 & 6 & 6 \\
\hline
\end{tabular}

\section{Verification of hypotheses $\mathrm{H}_{1}$ and $\mathrm{H}_{2}$ :}

To verify the hypotheses, we used the nonparametric Mann-Whitney test. The results are summarized in the following table (Table no. 5).

\section{Mann-Whitney Test}

Table 5 Statistical summary for $H_{1}$ and $H_{2}$

\begin{tabular}{|ll|r|r|r|}
\hline & \multicolumn{1}{|c|}{ SK } & \multicolumn{1}{c|}{ N } & Mean Rank & \multicolumn{1}{c|}{ Sum of Ranks } \\
\hline Comprehension & Control group & 126 & 98,18 & 12370,50 \\
& Experimental group & 126 & 154,82 & 19507,50 \\
& Total & 252 & & \\
\hline Specific transfer & Control group & 126 & 115,77 & 14586,50 \\
& Experimental group & 126 & 137,23 & 17291,50 \\
& Total & 252 & & \\
\hline
\end{tabular}


Table 6 Statistical summary for $H_{1}$ and $H_{2}$

\begin{tabular}{|l|c|c|}
\hline & Specific transfer & Comprehension \\
\hline Mann-Whitney U & 4369,500 & 6585,500 \\
Wilcoxon W & 12370,500 & 14586,500 \\
Z & $-6,293$ & $-2,495$ \\
Asymp. Sig. (2-tailed) & 0,000 & 0,013 \\
\hline
\end{tabular}

The results in Table 6 can be interpreted as follows: the value of the test criteria $\mathrm{Z}$ indicates that there are differences between values. In case of compliance $Z=0$. However, the test will be evaluated according to the value p - Asymp. Sig. (2-tailed) separately for comprehension and subsequently for a specific transfer.

\section{Data interpretation "comprehension":}

P-value is the probability of the error that would show up when we would reject the tested hypothesis. Since the calculated value of probability is $p_{(0,000)}<\alpha_{(0,05)}$, we reject the hypothesis $\mathrm{H} 0$ at the significance level $\alpha=0.05$, which in this case is: "Students using ETA and IWs during the learning process regarding the thematic units Coniferous and Deciduous Trees will achieve the same results in the category comprehension as students without ETA and IWs". This means that there is a statistically significant difference in the test results regarding comprehension between the control and experimental group. The results clearly speak in favor of the experimental group. Therefore we state that students from the EG group achieved better results in terms of comprehension and the difference is statistically significant. We thus confirm H1 hypothesis.

\section{A graphical comparison of the difference:}

Comprehension

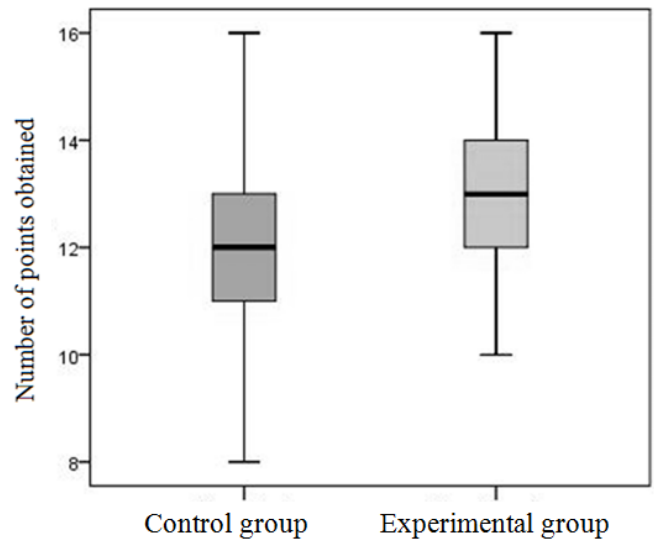

Figure 7 Graphical representation of $\mathrm{H}_{l}$ 
The box plots no. 7 is a very complex figure featuring all the essential characteristics of the division. Median is a thick black line. The lower and upper quartile determines the length of the box - interquartile range. The interquartile range is based on the breakdown of the distribution into four equal parts - quartiles. Border line represents the minimum and maximum values. Basic information about the concentration of the file can be read from the median's position within the box and the length of line segments from the upper and lower quartiles. In both groups we see that the values in the file are evenly distributed with a median in the middle of the box.

\section{Data interpretation "specific transfer":}

P-value is the probability of the error that would show up when we would reject the tested hypothesis. Since the calculated value of probability is $\mathrm{p}_{(0,013)}<\alpha_{(0,05)}$ we reject the hypothesis $\mathrm{H} 0$ at the significance level $\alpha=0.05$, which in this case is: "Students using ETA and IWs during the learning process regarding the thematic units Coniferous and Deciduous Trees will achieve the same results in the category specific transfer as students without ETA and IWs", in favor of the alternative hypothesis. This means that there is a statistically significant difference in test results regarding specific transfer between the control and experimental group. The results speak in favor of the experimental group, though the difference is not as evident as in the case of comprehension. Nevertheless, we can state that students from the EG group achieved better results in terms of the specific transfer. We thus confirm $\mathrm{H} 2$ hypothesis.

\section{A graphical comparison of the difference:}

\section{Specific transfer}

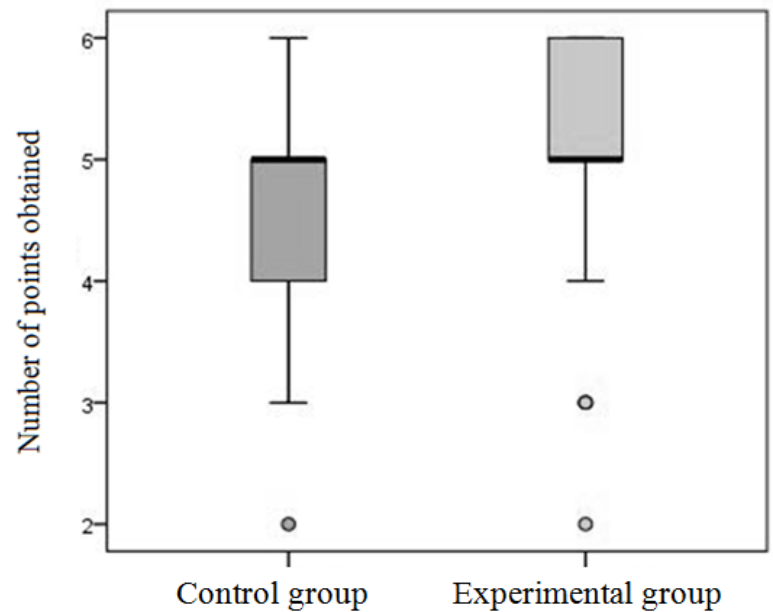

Figure 8 Graphical representation of $\mathrm{H}_{2}$

The box plot no. 8 shows us the median with the thick black line, lower and upper quartile determining the length of the box - interquartile range. Border lines represent the minimum and maximum values. Basic information about the concentration of the file 
can be read from the median's position within the box and the length of line segments from the upper and lower quartiles. In both groups we see that the values in the file are very unevenly distributed and medians are on the sides of the box - in the case of the control group they are on the border of the upper quartile and in the lower half at the border of the bottom quartile. In the control group the upper and lower quarter are uniformly distributed unlike the experimental group, where the maximum is identical with the maximum upper percentiles. This implies a significant impediment to the normal layout of files. Moreover, the experimental group features extreme value because it is located three times the length of the box away from the lower quartile. In both groups there is one value two boxes away from the lower quartile.

\section{Discussing the results achieved}

If we rely on theoretical assumptions briefly referred to in the section Application of interactive whiteboards in the education process in selected countries, we find common features relating to the modernization of the educational process and the transformation of traditional school into a modern school. This includes:

- justified need for using IWs in education, positive effect on the learning process, (Levy, 2002; Gerard et al., 1999; the results of the national project of the SR and KEGA-2015, presented research results);

- benefits for teachers, benefits for students (Smith, 1999, 2001; Levy, 2002 Bell, 2002) which significantly affects students' interest in the subject, the discussed issues, experiential learning of students, as confirmed by our research, since the students' interest in learning while using ITWs was enormous;

- the quality of the acquired knowledge affected by IWs (Neumajer 2008; Lehner, 2010; suitably proposed methodology and teaching strategies using IWs as confirmed by the results of the project KEGA-2015 and also our results, with a focus on understanding the facts and the specific transfer - applying acquired knowledge in typical situations);

- introducing IWs into subjects at primary and secondary schools is not a matter of fashion, but a legitimate phenomenon as evidenced by many studies in developed countries of Europe, in the United Kingdom and Slovakia (Hausner, 2009; project Rýchlá šetření roku 2008; Levy, 2002; Kennewell, 2001 ; Adamek et al., 2010; Bell 2002; Risgaard 2010, Lehner, 2010; and other authors, various national projects in Slovakia).

The use of IWs in the teaching process in specialized subjects taught at secondary vocational schools is justified, also demonstrated by the presented results. These results also confirm results of other researchers at home and abroad. Our achievements have limited validity, since the results cannot be generalized or cover other study programmes. However, the results clearly showed the merits and suitability of IWs in the teaching process of specialized subjects. IWs also impose requirements for a teacher to acquire competencies that enable him/ her to teach using IWs and other information and communication technologies, thus achieving specific educational goals in vocational subjects. 


\section{Conclusion}

One of the objectives of our research was to determine on the basis of pedagogical experiment whether the proposed and used electronic teaching aids (ETA) with the support of IWs will statistically affect students' knowledge in the educational process of the vocational subject Materials. The attention was given to the thematic units Coniferous and Deciduous Trees within the three-year study programme Carpenter in the Slovak Republic.

The results of the pedagogical experiment confirmed that the proposed application of ETAs and IWs significantly affects students' knowledge covered by this thematic unit. These significant results should become a postulate for teachers of vocational subjects in general and not only for teachers in this three-year study programme. Despite the difficulty in developing electronic teaching aids in symbiosis with the IW, teachers of vocational subjects should apply advanced approaches in the educational process and also use accessible information and communication technology in order to get students interested in learning and develop their creative thinking through experiential learning.

\section{Bibliography}

Adámek, R. a kol. (2010). Moderná didaktická technika v práci učitel’a. Košice: Elfa.

Bell, M. A. (2001).Why Use an Interactive Whiteboard? A Baker's Dozen Reasons. [online]. [citované 20. máj 2015]. Dostupné z:http://teachers.net/

Burton, S. (2010). Interactive white board: National Case studies [online]. Brussels:

Edward Prosser, Jim Ayre, Case Study: Switzerland. Dostupné z: http://moe.eun.org/c/document_library/get_file?uuid=2db0f7d1-089c-4a3a-b157-db3d65 a393b2\&groupId=10620

Ďuriš, M., Pavelka, J., \& Bendík, M. a kol. (2015). Implementácia interaktívnej tabule vo výučbe techniky, fyziky a matematiky vzákladnej škole. Prešov: Vydavatel'stvo prešovskej univerzity.

Gavora, P. a kol. (2010). Elektronická učebnica pedagogického výskumu. Bratislava: Univerzita Komenského.

Gerard, F., \& Widener, J. (1999). A SMARTer Way to Teach Foreign Language: The SMART Board Interactive Whiteboard as a Language Learning Tool. [online].[citované 20.máj 2015]. Dostupné z:http://edcompass.smarttech.com/en/learning /research/SBforeignlanguageclass.pdf.

Hausner, M. (2015). Př́padová studie European Schoolnet: Využivání interaktivních tabuli [online]. [citované 20. máj 2015]. Dostupné na<www:http://www.dzs.cz/index.php ?a=documents\&general_file_id=1541\&project_folder_id=377\&>

Chráska, M. (2007). Metody pedagogického výzkumu. Praha: Grada.

Kennewell, S. (2001). Using Affordances and Constraints to Evaluate the Use of Information and Communications Technology in Teaching and Learning [online]. [citované 20. máj 2015]. Dostupné z:http://www.tandfonline.com/doi/pdf/10.1080/ 14759390100200105.

Kopeček, M., \& Novák, T. (2010). This article contains mini-review about descriptive statistics. Praha: LF UK.

Lehner, K. a kol. (2010). Interactive White Board: National Case studies. Brussels: Edward Prosser. 
Levy P. (2002). Interactive whiteboards in learning and teaching in two Sheffield schools: A developmental study (Department of Information Studies, University of Sheffield). [citované 20. máj 2015].

Dostupné z http://dis.shef.ac.uk/eirg/projects/wboards.htm.

Markechová, D. a kol. (2011). Základy štatistiky pre pedagógov. Nitra: FPV UKF. Neumajer, O. (2008). Interaktivní tabule - vzdělávací trend $i$ módní záležitost [online].[citované 20. máj 2015]. Dostupné z: http:// http://ondrej.neumajer.cz/

Pavelka, J., Kozík, T., \& Bendík, M. a kol. (2015). Interaktívne prostredie a klúčové kompetencie. Prešov: Vydavatel'stvo prešovskej univerzity.

Risgaard, J. (2010). Interactive white board: National Case studies [online]. Brussels: Edward Prosser, Jim Ayre, Case Study: Denmark. Dostupné z: http://moe.eun.org/c/document_library/get_file?uuid=2db0f7d1-089c-4a3a-b157 $\mathrm{db} 3 \mathrm{~d} 65 \mathrm{a} 393 \mathrm{~b} 2 \&$ groupId=10620.

Rychlá šetření: Hlavni závěry projektu Rychlá šetřeni: Informační a komunikačni technologie ve školách Interaktivni tabule. Rychlá šetření 2009.(2009). Dostupné z: http://www.uiv.cz/clanek/17/1765.

SMITH, A. (1999). Interactive whiteboard evaluation. [online]. [citované 20. máj 2015]. Dostupné z: http://www.mirandanet.ac.uk/pubs/smartboards.htm.

Smith, H. (2001). Smartboard evaluation: final report. [online]. [citované 20. máj 2015]. Dostupné z: www.kented.org.uk/ngfi/whiteboards.

Ústav pro informace ve vzdělávání v rámci projektu Rychlá šetření 2008. (2008). [online]. [citované 20. máj 2015]. Dostupné na<http://www.msmt.cz/vzdelavani/dalsivzdelavani/rychla-setreni-2008>

http://www.minedu.sk/data/att/4796.pdf > [online]. [citované 20. máj 2015].

http://www.rirs.iedu.sk/Dokumenty/Používanie\%20interaktívnych\%20tabúl\%20v\%20slo venských\%20ZŠ\%20a\%20SŠ.pdf $>$ [online]. [citované 20. máj 2015].

http://www.bettshow.com/bett/website/Default. aspx?refer=1>. [citované 20. máj 2015].

https://www.eva.dk/>. [citované 20. máj 2015].

http://www.pisa.oecd.org $>$.[citované 20. máj 2015].

http://www.elc20.com/index.php/>.

http://www.km.fpv.ukf.sk/upload_publikacie/20120130_90405_1.pdf, 